\title{
METODE FUZZY INFERENSI SYSTEM MAMDANI UNTUK MENENTUKAN BANTUAN MODAL USAHA BAGI UMKM RAMAH LINGKUNGAN
}

\author{
Daniel Alfa Puryono \\ STIMIK AKI PATI \\ JL. Kamandowo No 13 Pati \\ E-mail : danielsempurna@gmail.com
}

\begin{abstract}
Government through various programs have attempted to increase the number of SMEs in the country. It is certainly motivated by the fact that Indonesia is still a shortage of entrepreneurs. Deficiencies in the micro business sector is an impact on the high unemployment because of the narrowness of employment so as to make the salaries of workers and employees are not too high. Many ways to determine appropriate criteria to get help entrepreneurial capital, one of which is by using fuzzy logic. This study aims to determine who is eligible to get help on using Mamdani fuzzy inference models or often also known as the min-max method. Analysis and design of the system to get the output is done in several steps: the formation of fuzzy set, Establishment of rules, rules of composition determination, Discernment (defuzzyfication). While the determination of entrepreneurial assistance based on the number of children in responsibility, large monthly income, Age prospective beneficiaries and friendly business environment. Of the report shows the results obtained proved to be better and more natural. We make this system is expected to assist the agency in making more informed decisions and accurately to determine recommendations to the beneficiary entrepreneurs. In addition, in order not to deviations and reduce the risk of corruption (Kolosi corruptions and nepotism). Because the report is valid and there is no duplication or manipulation of data.
\end{abstract}

Keywords : Fuzzy Inferensi Sytem Mandani; SMEs; Business Capital Assistance, Green

\section{Pendahuluan}

Kenaikan dolar atas rupiah yang terus menerus serta sering naiknya harga BBM (Bahan Bakar Minyak) mendorong meningkatnya biaya produksi bagi perusahaan maupun dunia usaha yang akan berdampak pula pada naiknya hargaharga produksi serta turunnya daya beli masyarakat, bertambahnya pengangguran, dan semakin meningkatnya jumlah penduduk miskin. Hal tersebut mengakibatkan pertumbuhan lapangan kerja lebih lambat dibandingkan dengan pertumbuhan angkatan pencari kerja sehingga bisa terjadi pengangguran yang berdampak terhadap terjadinya kemiskinan. Hal ini tentu dilatar belakangi oleh fakta bahwa Indonesia masih sangat kekurangan jumlah wirausahawan. Kekurangan pada sektor usaha mikro ini berimbas pada tingginya pengangguran lantaran sempitnya lapangan kerja sehingga menjadikan gaji buruh dan karyawan rendah.

Program Lingkungan PBB (UNEP; United Nations Environment Programme) dalam laporannya berjudul Towards Green Economy menyebutkan, green ekonomi adalah ekonomi yang mampu meningkatkan kesejahteraan dan keadilan sosial. Green ekonomi ingin menghilangkan dampak negatif pertumbuhan ekonomi terhadap lingkungan dan kelangkaan sumber daya alam. Dari definisi yang diberikan UNEP, pengertian green ekonomi dalam kalimat sederhana dapat diartikan sebagai perekonomian yang rendah karbon (tidak menghasilkan emisi dan polusi lingkungan), hemat sumber daya alam dan berkeadilan sosial.

Kemudian apa bedanya green economy dengan pembangunan berkelanjutan sustainable development. Konsep green ekonomi melengkapi konsep pembangunan berkelanjutan. Sebagaimana diketahui prinsip utama dari pembangunan berkelanjutan adalah "memenuhi kebutuhan sekarang tanpa mengorbankan pemenuhan kebutuhan generasi masa depan". Sehingga dapat dikatakan bahwa green ekonomi merupakan motor utama pembangunan berkelanjutan.

Sejalan dengan itu pemerintah salah satunya melalui Disperindag telah mencanangkan program untuk peningkatan taraf hidup masyarakat menengah dan kurang mampu dengan bantuan-bantuan yang diberikan, salah satunya adalah peningkatan ekonomi masyarakat melalui pemberian Bantuan Modal Usaha. Pemberian Bantuan Modal Usaha ini diperuntukkan bagi warga masyarakat yang kreatif, inovatif dan tetap memperhatikan faktor lingkungan yang telah memiliki usaha namun 
membutuhkan tambahan modal untuk pengembangan usaha. Khususnya untuk UMKM Makanan Ringan yang banyak di kabupaten Pati. Dengan adanya bantuan ini maka banyak masyarakat yang mengajukan permohonan untuk mendapatkannya.

Untuk mengatasi masalah diatas, maka perlu dilakukan analisis proses pemecahan masalah dengan penerapan sistem pendukung keputusan. Sistem pendukung keputusan dapat membantu dalam menganalisis pemilihan siapa yang layak menerima bantuan modal usaha sesuai dengan kriteria dan bobot yang telah ditetapkan sehingga pemberian modal tersebut tepat sasaran.

Banyak metode yang dapat digunakan dalam menerapkan sistem pendukung keputusan diantaranya menggunakan Fuzzy Inference System dengan Metode Mamdani. Logika fuzzy dan teori himpunan fuzzy menunjukkan potensi yang besar untuk menyelesain secara efektif permasalahan ketidak pastian. Penerapan logika fuzzy dalam bidang ekonomi dimulai pada awal tahun 70-an, setelah ada publikasi sebelumnya dari Zadeh (1965). Salah satu hal yang paling penting yang dibuat oleh Zadeh adalah Fuzzy Rule-Based System (FRBS) atau disebut juga dengan Fuzzy Inference System (FIS) (Zhao dkk.,2006). Fuzzy inference adalah proses merumuskan pemetaan dari input yang diberikan ke output dengan menggunakan logika fuzzy (Zhao dkk.,2006). Pemetaan kemudian menjadi dasar dari mana suatu keputusan diambil.

Beberapa penelitian terdahulu yang sudah terbukti berhasil mengunakan metode FIS Mamdani di antaranya tentang evaluasi nilai pencapaian hasil belajar siswa dengan menggunakan logika fuzzy (Gokmen, dkk. 2010). Tentang pemodelan sistem inferensi mamdani dalam memprediksi kekasaran permukaan menggunakan mesin laser (Sivarao, dkk 2009). Ada juga penelitian untuk menentukan jumlah produksi dengan aplikasi metode fuzzy-Mamdani (Djunaidi, dkk 2005).

Selain itu penelitian dengan menggunakan Metode Fuzy Infernce System (FIS) Mamdani juga pernah dilakukan, diantaranya untuk pemilihan suplier berdasarkan 3 kriteria, yaitu Economic (ekonomi), Environmental (lingkungan) dan Social (sosial). Data yang ada diolah berdasarkan ketiga kriteria tersebut menggunakan program aplikasi MATLAB dan akan didapatkan rekomendasi pemilihan suplier yang terbaik (Atefeh dkk, 2012).

Metode Fuzy Infernce System (FIS) yang di mengintegrasikan dengan Multi Criteria Decision Making (MCDM) untuk manajemen rantai pasokan global yang sesuai global logistik mode operasional. Dengan mengunakan tiga perkembangan fase utama yaitu : 1 . Pembentukan hierarki strategis Gobal Logistik, 2. Perumusan aturan identifikasi mode Gobal Logistik, dan 3. Pengembangan dari pilihan model Gobal Logistik mode. (Jiuh, 2008).

\section{Kerangka Teori}

\subsection{Himpunan Logika}

Himpunan merupakan kumpulan atau koleksi objek yang didefinisikan secara jelas dan pasti dalam sembarang urutan dan tak diperhatikan keberurutan objek - objek anggotanya. Objek objek itu disebut anggota atau elemen himpunan. Sedangkan logika adalah suatu displin yang berhubungan dengan metode berpikir. Pada tingkat yang paling dasar, logika memberikan aturan-aturan dan teknik-teknik untuk menentukan apakah suatu argumen yang diberikan adalah valid atau benar.

Fuzzy diperkenalkan oleh Lotfi A. Zadeh pada tahun 1965 sebagai cara matematis untuk merepresentasikan ketidakpastian linguistik. Berdasarkan konsep logika fuzzy, faktor-faktor dan kriteria-kriteria dapat diklasifikasikan tanpa batasan yang mengikat. Logika fuzzy sangat berguna untuk menyelesaikan banyak permasalahan dalam berbagai bidang yang biasanya memuat derajat ketidakpastian (Gokmen, dkk., 2010).

Pada himpunan klasik (crisp), keanggotaan suatu elemen (x) dalam suatu himpunan (A), sering dinotasikan dengan, hanya ada 2 nilai keanggotaan, yaitu untuk $\mathrm{x}$ menjadi anggota $\mathrm{A}$ dan untuk x bukan anggota dari A (Chak, 1998). Jika $\mathrm{X}$ adalah kumpulan obyek yang dinotasikan dengan $\mathrm{x}$, maka himpunan fuzzy dalam $\mathrm{X}$ adalah himpunan pasangan berurutan :

$$
A=\{(x, \mu A(x)) \mid x \in X\}
$$

Fungsi keanggotaan (membership function) adalah suatu kurva yang menunjukkan pemetaan titik-titik input data ke dalam nilai keanggotaannya (derajat keanggotaan) yang memiliki interval antara 0 sampai 1 . Salah satu cara yang dapat digunakan untuk mendapatkan nilai keanggotaan adalah dengan melalui pendekatan fungsi. Ada beberapa fungsi yang bisa digunakan, antara lain: representasi linear, representasi kurva segitiga, representasi kurva trapesium, representasi kurva bentuk bahu, representasi kurva-s, representasi kurva bentuk lonceng (Aslam dan Mahmudi, 2013).

\subsection{Fuzzy Inference System (FIS) Mamdani}

Metode Mamdani sering juga dikenal dengan nama Metode Max-Min. Metode ini 
diperkenalkan oleh Ebrahim Mamdani pada tahun 1975. Untuk mendapatkan output, diperlukan 4 tahapan: (1) Pembentukan himpunan fuzzy; (2) Aplikasi fungsi implikasi (aturan); (3) Komposisi aturan; (4) Penegasan (deffuzy) (Aslam dan Mahmudi, 2013).

1. Pembentukan himpunan fuzzy

Pada Metode Mamdani, baik variabel input maupun variabel output dibagi menjadi satu atau lebih himpunan fuzzy.

2. Aplikasi fungsi implikasi

Pada Metode Mamdani, fungsi implikasi yang digunakan adalah Min.

3. Komposisi Aturan

Tidak seperti penalaran monoton, apabila sistem terdiri-dari beberapa aturan, maka inferensi diperoleh dari kumpulan dan korelasi antar aturan. Ada 3 metode yang digunakan dalam melakukan inferensi sistem fuzzy, yaitu: max, additive dan probabilistik OR (probor).

a. Metode Max (Maximum)

Pada metode ini, solusi himpunan fuzzy diperoleh dengan cara mengambil nilai maksimum aturan, kemudian menggunakannya untuk memodifikasi daerah fuzzy, dan mengaplikasikannya ke output dengan menggunakan operator OR (union). Jika semua proposisi telah dievaluasi, maka output akan berisi suatu himpunan fuzzy yang merefleksikan konstribusi dari tiap-tiap proposisi. Secara umum dapat dituliskan :

$\mu_{\mathrm{sf}}[\mathrm{xi}]<--\max \left(\mu_{\mathrm{sf}}[\mathrm{xi}], \mu_{\mathrm{kf}}[\mathrm{xi}]\right)$

dengan:

$\mu \mathrm{sf}[\mathrm{xi}]=$ nilai keanggotaan solusi fuzzy sampai aturan ke-i;

$\mu \mathrm{kf}[\mathrm{xi}]=$ nilai keanggotaan konsekuen fuzzy aturan ke-i;

Apabila digunakan fungsi implikasi MIN, maka metode komposisi ini sering disebut dengan nama MAX-MIN atau MIN-MAX atau MAMDANI.

b. Metode Additive (Sum)

Pada metode ini, solusi himpunan fuzzy diperoleh dengan cara melakukan boundedsum terhadap semua output daerah fuzzy. Secara umum dapat dituliskan sebagai berikut:

$\mu \mathrm{sf}[\mathrm{xi}]<--\min (1, \mu \mathrm{sf}[\mathrm{xi}]+\mu \mathrm{kf}[\mathrm{xi}])$

dengan:

$\mu \mathrm{sf}[\mathrm{xi}]=$ nilai keanggotaan solusi fuzzy sampai aturan ke-i;

$\mu \mathrm{kf}[\mathrm{xi}]=$ nilai keanggotaan konsekuen fuzzy aturan ke-i;

c. Metode Probabilistik OR (Probor)
Pada metode ini, solusi himpunan fuzzy diperoleh dengan cara melakukan product terhadap semua output daerah fuzzy. Secara umum dapat dituliskan sebagai berikut :

$\mu \mathrm{sf}[\mathrm{xi}]<--(\mu \mathrm{sf}[\mathrm{xi}]+\mu \mathrm{kf}[\mathrm{xi}]$ -

$\left(\mu \mathrm{sf}[\mathrm{xi}]^{*} \mu \mathrm{kf}[\mathrm{xi}]\right)$

dengan:

$\mu \mathrm{sf}[\mathrm{xi}]=$ nilai keanggotaan solusi fuzzy sampai aturan ke-i;

$\mu \mathrm{kf}[\mathrm{xi}]=$ nilai keanggotaan konsekuen fuzzy aturan ke-i;

4. Penegasan (defuzzy)

Input dari proses defuzzifikasi adalah suatu himpunan fuzzy yang diperoleh dari komposisi aturan-aturan fuzzy, sedangkan output yang dihasilkan merupakan suatu bilangan pada domain himpunan fuzzy tersebut. Sehingga jika diberikan suatu himpunan fuzzy dalam range tertentu, maka harus dapat diambil suatu nilai crsip tertentu sebagai outputnya.

Ada beberapa metode defuzzifikasi pada komposisi aturan MAMDANI, antara lain:

a. Metode Centroid (Composite Moment)

Pada metode ini, solusi crisp diperoleh dengan cara mengambil titik pusat $\left(\mathrm{z}^{*}\right)$ daerah fuzzy. Secara umum dirumuskan:

$z^{*}=\frac{\int_{Z} z \mu(z) d z}{\int_{Z} \mu(z)}$ atau $z^{*}=\frac{\sum_{j-1}^{n} z_{j} \mu\left(z_{j}\right)}{\sum_{j-1}^{n} \mu\left(z_{j}\right)}$

\section{b. Metode Bisektor}

Pada metode ini, solusi crisp diperoleh dengan cara mengambil nilai pada domain fuzzy yang memiliki nilai keanggotaan separo dari jumlah total nilai keanggotaan pada daerah fuzzy. Secara umum dituliskan:

$$
\int_{\Re_{1}}^{p} \mu(z) d z=\int_{p}^{\Re_{n}} \mu(z) d z
$$

\section{c. Metode Mean of Maximum (MOM)}

Pada metode ini, solusi crisp diperoleh dengan cara mengambil nilai rata-rata domain yang memiliki nilai keanggotaan maksimum.

\section{d. Metode Largest of Maximum (LOM)}

Pada metode ini, solusi crisp diperoleh dengan cara mengambil nilai terbesar dari domain yang memiliki nilai keanggotaan maksimum.

e. Metode Smallest of Maximum (SOM)

Pada metode ini, solusi crisp diperoleh dengan cara mengambil nilai terkecil dari domain yang memiliki nilai keanggotaan maksimum. 


\subsection{Manajemen Ramah Lingkungan}

Ramah linglungan merupakan kata kunci untuk meyakinkan bahwa semua faktor atau semua elemen dalam usaha memperhatikan lingkungannya atau tidak menimbulkan dampak berbahaya bagi lingkungan. Ramah linglungan bertujuan untuk membatasi limbah yang dihasilkan dalam sistem industri atau perusahaan supaya dapat menghemat energi serta ekonomis dan efisien sumber daya. Pengukuran kinerja ramah lingkungan harus sesuai dengan prinsip sistem manajemen lingkungan (Puryono, 2014).

Sedangkan manfaat dari penerapan ramah lingkungan sebagai berikut :

1. Peningkatan ekonomi melalui peningkatan efisiensi.

2. Keuntungan berkompetisi melalui inovasi.

3. Meningkatkan kualitas produk.

4. Meningkatkan citra perusahaan.

5. Memelihara konsistensi terhadap lingkungan.

6. Konservasi alam dan pengurangan limbah.

\section{Metodologi}

Sistem Inferensi Fuzzy adalah sistem aturan berdasarkan logika fuzzy dimana digunakan sebagai alat untuk mewakili pengetahuan yang berbeda tentang suatu masalah, serta untuk memodelkan interaksi dan hubungan yang ada antara variabel tersebut. Sistem Inferensi Fuzzy yang diusulkan akan digunakan untuk membantu pemerintah dalam penentuan pemberian bantuan usaha bagi masyarakat.

Sistem yang diusulkan terdiri dari 4 input, 1 output, dan 81 aturan untuk menghasilkan keputusan apakah pemohon layak menerima bantuan tersebut.

Untuk pengujian sistem dilakukan dengan menginput data sampel sekitar 10 orang pemohon bantuan modal usaha. Table 1 menunjukan data tentang sampel 10 orang pemohon dengan hasil output sebagai berikut :

Tabel 1. Data Pemohon Bantuan Modal

\begin{tabular}{|l|l|l|c|c|l|l|}
\hline Nama & $\begin{array}{l}\text { Pengha } \\
\text { silan/bl } \\
\text { n (Juta) }\end{array}$ & Umur & $\begin{array}{l}\text { Jml } \\
\text { Tangg } \\
\text { ungan }\end{array}$ & $\begin{array}{l}\text { Ramah } \\
\text { Lingku } \\
\text { ngan }\end{array}$ & Nilai & Hasil \\
\hline Jalil & 1 & 35 & 5 & $\mathrm{~S}$ & 0.6 & $\begin{array}{l}\text { dipertim } \\
\text { bangkan }\end{array}$ \\
\hline Supi & 1.2 & 33 & 3 & $\mathrm{~S}$ & 0.52 & $\begin{array}{l}\text { dipertim } \\
\text { bangkan }\end{array}$ \\
\hline Isah & 1.7 & 45 & 4 & RL & 0.75 & diterima \\
\hline Suri & 2 & 30 & 0 & Tdk RL & 0.45 & ditolak \\
\hline Andi & 2.3 & 40 & 4 & RL & 0,68 & diterima \\
\hline Ari & 2.5 & 47 & 5 & RL & 0,90 & diterima \\
\hline Paidi & 1.5 & 40 & 4 & S & 0,60 & $\begin{array}{l}\text { dipertim } \\
\text { bangkan }\end{array}$ \\
\hline Adul & 1.25 & 38 & 2 & Tdk RL & 0,45 & ditolak \\
\hline Jaja & 2.25 & 33 & 2 & Tdk RL & 0,45 & ditolak \\
\hline Rudi & 2.5 & 48 & 3 & RL & 0,75 & diterima \\
\hline
\end{tabular}

Langkah-langkah penelitian sebagai berikut :
1. Pengumpulan Data

Meliputi data calon penerima bantuan, data penghasilan, data usia, data jumlah tangungan dan data UMKM Makanan ringan yang ramah lingkungan.

2. Identifikasi Data

Identifikasi data dilakukan untuk menentukan variabel dan semesta pembicaraan yang diperlukan dalam melakukan perhitungan dan analisis masalah.

3. Pengolahan Data

Pengolahan data dilakukan dengan menggunakan bantuan sofware Matlab (Prabowo, 2012). dengan menggunakan fasilitas yang disediakan pada toolbox fuzzy dan melakukan langkah-langkah sebagai berikut:

Pembentukan himpunan fuzzy, pembentukan aturan-aturan, penentuan komposisi aturan, penegasan (defuzzy) dan pengujian.

Sebelum melakukan langkah-langkah di atas terlebih dahulu dilakukan peramalan. Hal ini dilakukan untuk meramalkan permintaan yang akan mendapatkan bantuan wirausaha.

4. Penarikan Kesimpulan

Berikut adalah daigram alir untuk penarikan kesimpulan

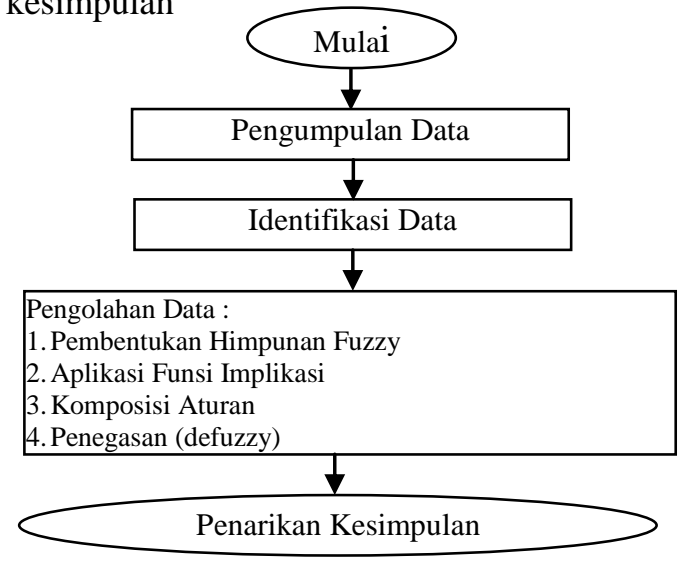

Gambar 1. Diagram Alir Penelitian

\section{Hasil dan Pembahasan}

\subsection{Hasil Penelitian}

Penelitian ini menghasilkan sebuah penentuan bantuan modal usaha untuk UMKM Makanan ringan yang ramal lingkungan menggunakan Fuzzy Inference System Mamdani dengan nilai kebenaran yang sangat baik. Jadi metode Mamdani paling sesuai dengan naluri manusia, bekerja berdasarkan kaidah linguistik dan memiliki algoritma fuzzy yang menyediakan aproksimasi untuk dimasuki analisa matematik serta ramah lingkungan.

\subsection{Kerangka Pemodelan Sistem}

Berikut adalah dasar pengetahuan yang menggambarkan perilaku sistem yang diwakili 
oleh fungsi keanggotaan variabel linguistik berdasarkan pada sistem pendukung keputusan.

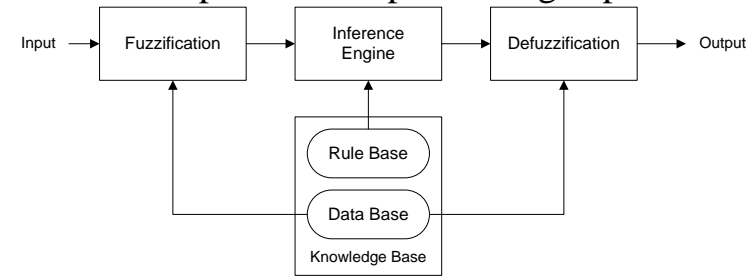

Gambar 2. Diagram Blok pada FIS

Jika di imlementasikan serta dimasukkan datadata dan variabel-veriabel yang sudah ditentukan pada program Matlab, Maka rancangan sistemnya akan seperti pada gambar 3 dibawah ini :

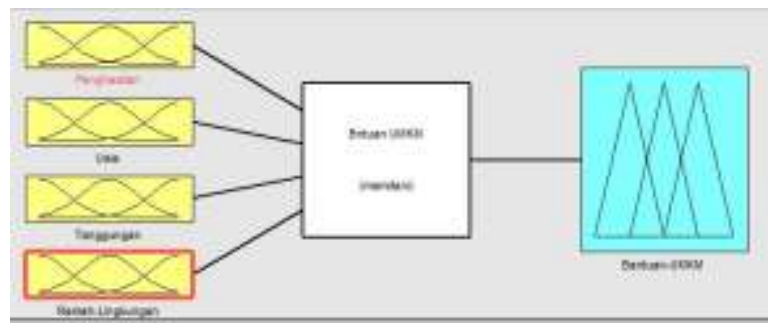

Gambar 3. Diagram FIS Bantuan UMKM

\subsection{Masukan}

Dalam fuzzy inference system ini ada 4 buah input variabel yang merupakan masukan data pemohon diantaranya penghasilan, usia dan jumlah tanggungan

a. Penghasilan

Yaitu jumlah penghasilan per bulan atau omset usaha yang yang telah dijalankan pemohon. Nilai domain dari variabel penghasilan adalah sebagai berikut :

1) Rendah : (1.000.000 - 1.500.000)

2) Sedang: $:(1.250 .000-2.250 .000)$

3) Tinggi : (1.750.000 - 2.750.000)

Fungsi keanggotaan dari variabel penghasilan dijelaskan dalam gambar 4 berikut :

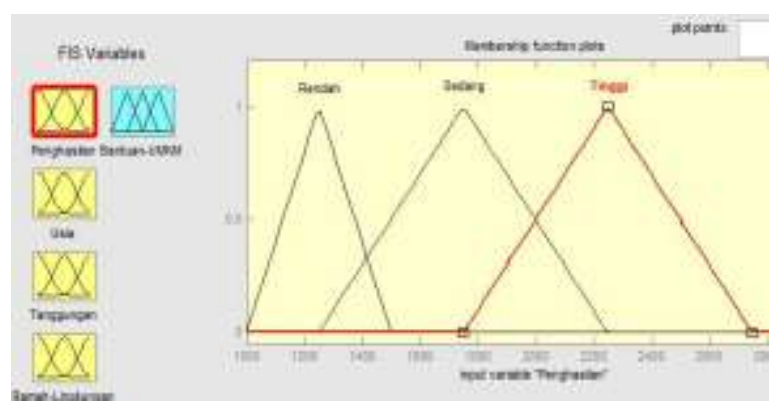

b. Usia

Gambar 4. Fungsi Variabel Penghasilan

Yaitu usia dari pemohon dihitung tanggal lahir sampai tanggal mengajukan permohonan. Nilai domain dari variabel usia adalah sebagai berikut :
1) Muda
$:(20$ th -40 th $)$
2) Parobaya : (30 th -50 th)
3) Tua
: (40 th -60 th)

Fungsi keanggotaan dari variabel usia dijelaskan dalam gambar berikut :

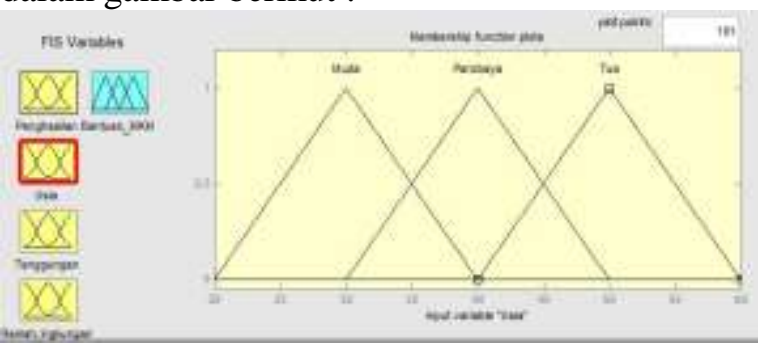

Gambar 5. Fungsi Variabel Usia

c. Tanggungan

Adalah jumlah tanggungan (anak dan istri) yang dimiliki pemohon. Nilai domain dari variabel tanggungan adalah sebagai berikut :

1) Sedikit : ( $\left.\begin{array}{ll}0 & 3\end{array}\right)$

2) Sedang: (2 5)

3) Banyak: (4 6)

Fungsi keanggotaan dari variabel tanggungan dijelaskan dalam gambar berikut :

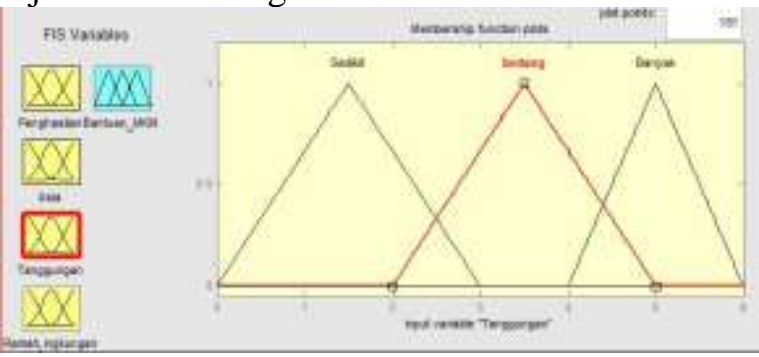

Gambar 6. Fungsi Variabel Tanggungan

d. Ramah lingkungan (Green)

Termasuk bahan yang digunakan, proses pembuatan, pemanfaatan daur ulang yang sudah dilakunan UMKM. Nilai domain dari variabel ramah lingkungan adalah sebagai berikut :

1) Tidak ramah lingkungan : $(1.0-3.0)$ point

2) Standart : $(3,1-5,5)$ point

3) Ramah lingkungan : $:(5,6-10)$ point

Fungsi keanggotaan dari variabel tanggungan dijelaskan dalam gambar berikut :

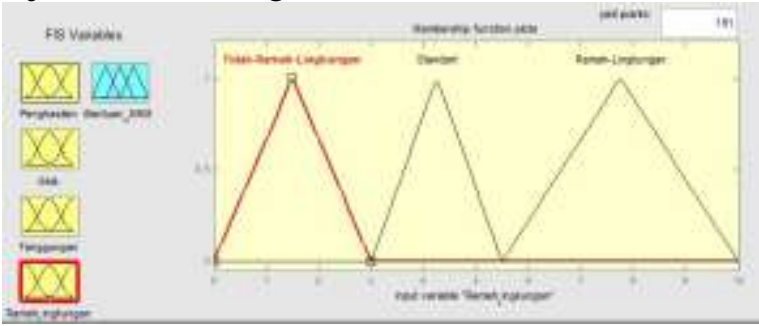

Gambar 7. Fungsi Variabel Ramah Lingkungan

\subsection{Aturan (Rule Base)}

Dalam membuat sistem berbasis aturan ini memiliki sekumpulan fakta yang mewakili working memory. Aturan ini mencakup setiap tindakan yang harus diambil dalam ruang lingkup permasalahan yang dibutuhkan. Serta kondisi yang menentukan bahwa solusi telah ditemukan atau tidak (none exist). Hal ini berguna untuk menghindari looping yang tidak akan pernah berakhir. Dalam sistem ini 
ada 81 aturan yang telah ditetapkan oleh Disperindag Pati untuk menyeleksi pemohon yang benar benar layak untuk menerima bantuan.

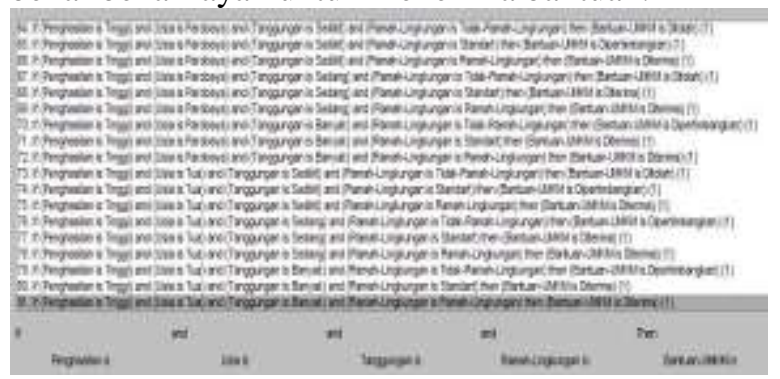

Gambar 8. Rule Base

\subsection{Keluaran}

Output merupakan hasil dari proses input dan aturan (rule base) menghasilkan keterangan apakah pemohonan bantuan tersebut ditolak, dipertimbangan, atau direkomendasikan. Nilai domain dari variabel Penghasilan adalah sebagai berikut
1) Ditolak
$:(0.0-0,5)$
2) Dipertimbangkan : $(0,25-0,75)$
3) Diterima
$:(0,5-1.0)$

Fungsi keanggotaan dari variabel Output Bantuan dijelaskan dalam gambar berikut :

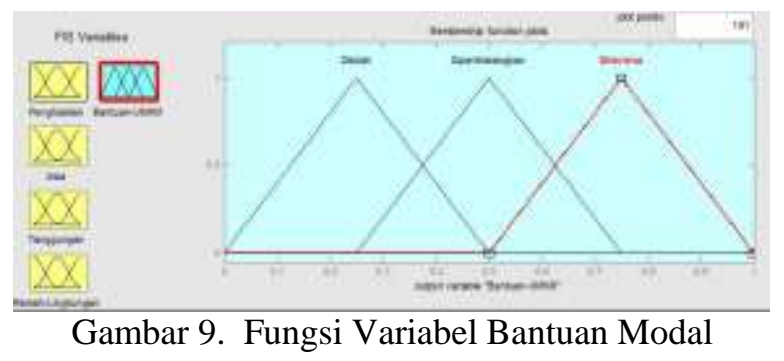

\subsection{Surface Viewer}

Berguna untuk melihat gambar pemetaan antara variabel-variabel input dan variabel-variabel output.

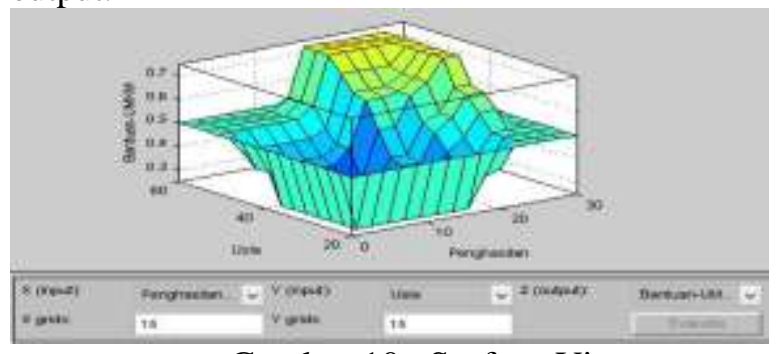

Gambar 10. Surface Viewer

\section{Kesimpulan}

Berdasarkan kegiatan selama perancangan dan implementasi pada proses pembuatan aplikasi Fuzzy Inference System untuk penentuan bantuan modal usaha menggunakan metode mamdani, maka dapat diambil beberapa kesimpulan seperti berikut:

Metode penelitian sistem yang digunakan adalah Fuzzy Inference System Metode Mamdani dengan nilai kebenaran mencapai $80,75 \%$. Jadi metode Mamdani paling sesuai dengan naluri manusia, bekerja berdasarkan kaidah linguistik dan memiliki algoritma fuzzy yang menyediakan aproksimasi untuk dimasuki analisa matematik. Data yang diolah dalam metode mamdani yaitu penghasilan dari usahanya yang selama ini dijalankan, usia, jumlah tanggungan keluarganya dan Data UMKM yang ramah lingkungan. Data tersebut diposes melalui tahap-tahap perhitungan logika fuzzy dan memberikan keluaran dari sistem berupa rekomendasi calon penerima bantuan.

Aplikasi penentuan bantuan modal usaha yang dikembangkan dapat membantu para pengambil kebijakan dalam hal ini pemerintah dalam memilih para pengusaha UMKM yang mengajukan permohonan bantuan modal dengan kemungkinan hasil yang terbaik karena setiap perhitungan diperoleh dari kriteria - kriteria yang dikehendaki oleh pengambil kebijakan.

\section{Daftar Pustaka}

Aslam F, Mahmudi, A.A, 2013. Penentuan Modal Wirausaha Baru Mengunakan Metode FIS Mamdani. Potensio, 19, 46-53.

Atefeh Amindous, Shamsuddin Ahmed, Ali Saghafinia, Ardeshir Bahreininejad., 2012. Sustainable Supplier Selection: A Ranking Model Based On Fuzzy Inference System, International Journal of Applied Soft Computing 12, 1668-1677.

Djunaidi, M., Setiawan, E., Andista, F.W., 2005 Penentuan Jumlah Produksi dengan Aplikasi Metode Fuzzy - Mamdani, Jurnal Ilmiah Teknik Industry. 4, 95-104.

Gokmen, Akinci, Tektas, Onat, 2010, Evaluation of Student Performance In Laboratory Applications using Fuzzy Logic, Procedia Socialand Behavioral Sciences 2, 902-909.

Jiuh Biing Sheu., 2008. A Hybrid Neuro-fuzzy Analytical Approach to Mode Choice Of Global Logistics Management, European Journal of Operational Research 189, 971-986.

Prabowo Pudjo W. dan Rahmadya TH, 2012. Penerapan Soft Computing dengan MATLAB. Edisi Revisi. Penerbit Rekayasa Sains Bandung.

Puryono, D.A 2014. Penerapan Green Supply Chain Management Untuk Meningkatkan Kinerja Keuangan Perusahaan, Thesis. Universitas Diponegoro Semarang.

Sivarao, Peter Brevern, N.S.M. El-Tayeb., 2009. GUI Based Mamdani Fuzzy Inference System Modeling To Predict Surface Roughness in Laser Machining, International Journal of Electrical \& Computer Sciences 9, 37-43

Zhao Guopeng, Levin, Prof Wlodzislaw Duch., 2006. Data Analysis with Fuzzy Inference System. 